\title{
Analysis of Historical Learning on Attitude and Interests of MA Al-Muhajirin Students
}

\author{
Agus Susilo \\ History Education Program of STKIP PGRI, Lubuklinggau \\ e-mail: agussejarah2020@gmail.com \\ Isbandiyah \\ History Education Program of STKIP PGRI, Lubuklinggau
}

\begin{abstract}
Learning history is now very vital at the high school level. The presence of the 2013 curriculum makes assessment in learning history not only seen from the learning outcomes obtained by students at the end of the semester, but also the process of attending school activities. The purpose of writing this scientific article is to analyze the history of learning towards the attitudes and interests of MA AlMuhajirin students. In writing this scientific article, the writer is based on observational aspects that exist in MA Al-Muhajirin. From the author's observations that are supported by references that support the data obtained to be a reference writing this scientific article. discussion related to the analysis of historical learning on the attitudes and interests of MA Al-Muhajirin's students is known that the values of historical learning are very important in shaping the attitude of Al Muhajirin's students. How the history teacher makes it important and arouse students' interest in participating in history learning. Learning history that is well followed and always innovating will produce a good new nuance. His conclusion by following history learning well and the ability to innovate history teachers will add insight and knowledge to the development of students' attitudes and interests in learning.
\end{abstract}

Keywords: History, Attitudes and interests, Students

\section{INTRODUCTION}

According to Neolaka and Neolaka in (Triwiniastuti \& Sabatini, 2019: 54), education is an effort to improve the standard of human life both physically and spiritually. This is in line with Ki Hajar Dewantara's view, that education is an effort to advance the character, mind, and body of children, in order to advance the perfection of life, namely to live and bring children to life in harmony with nature and society. Whereas in Law no. 20/2003 (Law No. 20/2003) on the National Education System, education is a conscious, planned effort to create an atmosphere of learning and process of learning so that students actively develop their potential to have spiritual spiritual strength, self-control, personality, intelligence, morals noble, as well as the skills it needs, society, nation and State

Making sure to everyone, especially teachers, who are professionally engaged in work is the first effort that must be made in order to achieve educational standards that match expectations. Teaching is not just conveying subject matter, but also a process that seeks to change student behavior with expected goals. Therefore, in the teaching process there are activities to guide students so that students can develop according to 
their developmental tasks, and train skills both intellectual skills and motor skills so the students dare to live in a society that is rapidly changing and full of competition, motivating students so that they can solve various problems of life in a society full of challenges and obstacles, forming students who have high intellectual and innovative abilities to be more creative in following history lessons.

Therefore, a teacher needs to have the ability to design and implement various learning strategies that are deemed suitable to the interests and talents and according to the level of student development including using various kinds of learning summers and learning media to ensure the effectiveness of learning Today's teachers still have to learn and have a professional attitude in guiding students with their competencies. The formation of student attitudes is very important in the current era so that in the future students have a good spirit and develop in the community. Interest in learning history is very important with various creations from teacher innovations in shaping lessons to be interesting. In addition, interest in learning must grow in students so that students consider history lessons important. Students learn to orientate not only values but also good character (Sanjaya, 2016: 14-15).

The teacher's function in planning and implementing the learning process is a major factor in achieving learning objectives. The skills to plan and implement this learning process are closely related to the duties and responsibilities of the teacher as an educating teacher. Teachers as educators have a very broad meaning, not only providing teaching materials, but reaching out to ethical and aesthetic behavior in facing the challenges of life in society. Creativity and competence are among the most important teacher qualifications. If creativity and competence are not present in a teacher, he will not be competent in doing his job and the results will not be optimal. The ability of teachers to develop the learning process and their mastery of teaching materials is not sufficient. The teacher's ability to master the class is balanced with the ability to evaluate student competency planning which is very decisive in the context of subsequent planning, or the policy of treating students related to the concept of complete learning (Hasyim, 2014: 265-266).

Al-Muhajirin High School students in taking history lessons always need strong guidance. Just like other students, strengthening history lessons still seems to be memorizing and results-oriented, that is, to get good grades. So that history teachers at Al-Muhajirin High School made a new breakthrough by utilizing historical learning media sources to provide a real-life picture of history lessons and can be easily understood by students. Applying various kinds of media according to the needs in order to be attractive to students. The enthusiasm of these history teachers was motivated by the students' condition towards history subject matter which was considered less attractive, even seemed boring

History is the science that studies events or events in the past to be used as a guide for the present and the future. In relation to history, Sartono Kartodirdjo (2005) said that history is a story about the collective experience of a community of a nation in the past which will shape the national personality and simultaneously determine the national identity of the nation. A person who studies history, in turn, will have historical insight. By having historical insight, a person will be able to conceptualize a useful history to anticipate the future, including in nation building. Thus, historical reflections can be used as objects in the barometer of national development that is dignified, civilized, and has socio-cultural wisdom (Sulaiman, et al, 2018: 238). 
The application of media in learning history cannot be separated from the aspect of need. However, the teacher must look at the aspects of the situation in accordance with the school where the teacher serves. Historical learning, which basically teaches past life on the sheets of history books, must be able to be developed into more interesting works. Students will feel comfortable in learning when learning is interesting and fun for students. However, the application of the media must pay attention to the importance of shaping student attitudes and interest in taking history lessons. MA AlMuhajirin students, although studying in a village setting, by applying the media in learning history, will make students more active and provide benefits. The purpose of writing this article is clear, that for the Analysis of Historical Learning of the Attitudes and Interests of MA Al-Muhajirin Students.

\section{RESEARCH METHODS}

Scientific articles are analyzed using a qualitative descriptive method that focuses on observing the analysis of historical learning on the attitudes and interests of MA Al-Muhajirin students. Qualitative researchers who change problems after entering the field while conducting research activities to make them better. It is done in order to be able to see the phenomenon more broadly and deeply in accordance with what is happening and developing in the social situation under study. The instrument used is direct observation which is described with various relevant reference sources to support the writing of the scientific paper. The results of direct observations described with sources related to writing scientific articles are written based on existing conditions.

\section{FINDING AND DISCUSSION}

\section{Learning History on Attitudes and Interests of MA Al-Muhajirin Students}

In the trust of Law No. 20 of 2003, that education not only forms Indonesian intelligent people, but also personality, so that later will be born a generation of nations that grow and develop with a character that breathes the noble values of the nation's culture and religion. Character education is a system of cultivating character values that include the components of knowledge (cognitive), awareness or feeling, and action (action) to implement these values, both to God Almighty, oneself, among others, social environment, as well as in national and state life. When observed properly, the actual character refers to a series of attitudes, behaviors, motivations, and skills. The term character is concerned with one's personality. A person is said to have a character (a person of character) when his behavior is in accordance with the values, norms or moral rules that apply in social life (Brata, 2019: 53).

History is a picture of the past about humans and their surroundings as social creatures that are scientifically and completely compiled, covering the sequence of facts of the period with interpretations and explanations that give understanding of what has passed. History in its function is not only to remember the past but history is a reflection of the activities of human life in the past at the present. History is like a compass for life or the basis for a pilot to make decisions, because history is the crystallization of all knowledge, all knowledge and all that has been learned since humans existed. Such conditions allow history to raise universal values contained in every form of human culture. Thus history education is not only directed at instilling an understanding of the past to the present, fostering a sense of the development of a national society and love 
for the country and a sense of pride as Indonesian citizens and broadening the horizons of public relations between nations in the world (Werang Kean, 2018: 255) .

According to Sayono in (Tabrono, et al, 2020: 17-18), the requirements for history teachers, among others 1) must have academic ability, especially mastery of the material. The academic ability of teachers is at least indicated by the educational background that comes from the history or history education majors. Of course, it cannot be used as a guarantee that a person with a history of education must have good academic abilities, but at least they will be educated for this. In the implied academic ability, the teacher really understands the character of each material, 2). methodic didactic (pedagogical) abilities. Methodic didactic ability is the teacher's ability to carry out history learning.

Historical awareness and historical insight have a great relationship. Every society is always influenced by historical insights. Historical awareness that appears in a person and / or society is a reflection of his historical insight. Each culture displays a form of historical awareness that is different from other cultures. Insights into the realization of history change their historical awareness. Conversely, changes in historical consciousness affect him in seeing reality, giving rise to a qualitative leap in seeing himself in the historical process (Susilo \& Ratna, 2019: 3-4).

The teacher must use a method that can make the classroom atmosphere a place with high standards and everyone in it can work hard in a laboratory where the teacher and students work together as a team to find solutions to important problems and achieve significant results. Solutions in learning history must be completed immediately so that learning conforms to the desired rules. History teachers can conduct lessons, conduct group discussions, and conduct research projects. He must also be able to write scripts and portray various characters. Teachers and students in the digital age can explore, discover, and develop their learning potential in a knowledge-based society. The development of learning resource centers that integrate technology in providing information services provides many opportunities to help the effectiveness and efficiency of the learning process. Teachers and students can get up-to-date learning resources, and even receive submissions of various learning materials in digital formats (for example e-books and ejournal) and multimedia (Susilo \& Isbandiyah, 2019: 175176).

In observations made by researchers at MA Al-Muhajirin, especially in learning history which was applied by history teachers there, it was found that students in learning needed guidance in the history learning. There should also be more books related to history lessons. History teachers are indeed required to be creative in teaching history, but they must also adjust their needs and supporting infrastructure. The majority of history teachers at MA Al-Muhajirin are still relatively young in understanding learning media innovations that add insight to students in taking history lessons. Apart from media innovation in historical learning, the latest models must be used to vary the teaching.

Professional teachers are not only required to master learning material but must also master all aspects of learning, because the meaning of learning is learning that involves students and covers all learning areas, such as cognitive aspects (thinking), affective aspects (behavior) and psychomotor aspects (skills). Teachers as professional educators have a good image in society if they can show the community that they are worthy of being role models around them, the community will especially see the teacher's daily attitudes and actions. To create a professional teacher in giving birth and 
improving the quality of human resources, it is necessary to explain in this paper from the point of view of teacher professionalism in improving the quality of human resources (Yusutria, 2017: 40).

A teacher must use a method that can make the classroom atmosphere like a place with high standards and everyone in it can work hard and together with students work together as a team to find solutions to important problems and achieve significant results. History teachers must have a good knowledge of the use and operation of new types of mechanical aids, such as epidiascopes, filmstrip projectors, and film projectors. History teachers should be given the opportunity to attend historical conferences at the local, regional, and national levels, and take part in discussions about textbooks and audiovisual methods used by their own and other countries. History teachers must have knowledge of the studies carried out by UNESCO on various aspects of the nation. It must study international organizations in relation to their historical evolution. Historical awareness is nothing but a psychological condition which shows the level of appreciation of the meaning and essence of History for the present and for the future. In this case, discourse about the past will not only give birth to historical knowledge, in turn it will also demand not to be separated from society's impulses towards the birth of historical events, where history is always born by contemplation about the 'fate of humanity' (Susilo \& Sarkowi, 2018: 49).

One indicator of a professional teacher is when he has awareness to always learn and develop his competence continuously as long as he devotes himself in education. To realize this, the government is trying to organize a teacher competency improvement program called the learner teacher program. This program aims to provide motivation and awareness to always learn through the process of self-development, but the essence of this program is (1) teachers are required to be able to adapt new changes, namely the development of science and technology, (2) be able to apply learning methods, models and strategies that are able to facilitate students so that they have the ability of human resources in the 21st century (Richardo, 2016: 784).

History teachers are vital in shaping students' attitudes and interests in learning history. There are values in every lesson, including history lessons. History lessons that many students ignore, basically have the value of local wisdom which is very important for the life to come. The heroic histories of freedom fighters, the system of struggle against the colonialists, and heroic figures should be introduced to students in schools more widely. The wisdom contained in historical subjects can foster a high attitude of nationalism and distance from an indifferent attitude towards the life of one's own people. Thus, the role of the history teacher to explore the souls of innovation in shaping historical material becomes more interesting for students to follow in school. Inculcating student character values through history lessons can be applied today in the midst of modernization.

For students, it is also very vital in taking history lessons in school. It must be known and realized that students are the nation's next generation. So it is better to follow lessons in school properly and correctly. The role of history teachers in helping to shape the character of the nation's children is enormous. Presenting media in the school environment is also very good so that learning runs as it should. A conducive school environment, innovative teachers and students with a nationalistic spirit will form a young generation who are intelligent and beneficial to the nation and the State. Ages may change with technological advances that flood the Indonesian nation, but 
maintaining the integrity of the Indonesian State by studying history properly and correctly will be very beneficial for future life.

\section{CONCLUSIONS}

Learning history at the SMA / MA level is very vital because it focuses on core material that stands on its own. At MA Al-Muhajirin, learning history programs are continuously improved, including the use of media as a historical source. History teachers continue to learn how to innovate historical media that can be applied in these schools. The current learning history which is applied not only wants achievement, but also the formation of a good attitude and interest in learning history. It is clearly stated in the 2013 curriculum, where the assessment is not only in the aspect of achievement, but also in the formation of good attitudes. In history learning, there is a spirit of nationalism, local wisdom, virtue, and so on, which teachers must develop to students through a learning innovation. Learning development is basically based on the aspects of needs and also the demands contained in the 2013 curriculum.

\section{REFERENCES}

Brata, I. B. (2019). Nilai-Nilai Pendidikan Karakter dalam Gending Rare sebagai Upaya Melestarikan Kearifan Lokal Bali. 19(1), 50-65.

Hasyim, M. (2007). Penerapan fungsi guru dalam proses pembelajaran. (36), 265-276.

Richardo, R. (2016). Program Guru Pembelajar : Upaya Peningkatan Profesionalisme Guru Di Abad 21. (November), 777-785.

Sanjaya, W. (2016). Strategi Pembelajaran Berorientasi Standar Proses Pendidikan. Jakarta: Prenadamedia Group.

Sulaiman, Hasti, D. (2018). Menelusuri Jejak Sejarah Peninggalan Portugis di Kampung Numba. Jurnal Historia, 6(2), 237-250.

Susilo, Agus \& Wulansari, R. (2019). Kuliah Lapangan Sejarah Sebagai Penguatan Pendidikan Karakter Mahasiswa STKIP PGRI Lubuklinggau. Criksetra: Jurnal Pendidikan Sejarah, 8(2), 1-17.

Susilo, A. \& I. (2019). Peran Guru Sejarah dalam Pembentukan Pendidikan Karakter Anak Era Globalisasi. IJSSE: Indonesian Journal of Social Science Education, 1(2), 171-180.

Susilo, A., \& Sarkowi, S. (2018). Peran Guru Sejarah Abad 21 dalam Menghadapi Tantangan Arus Globalisasi. Historia: Jurnal Pendidik Dan Peneliti Sejarah, 2(1), 43. https://doi.org/10.17509/historia.v2i1.11206

Tabroni, R., Zakaria, M. M., Dienaputra, R. D., \& Mulyadi, R. M. (2020). Memandang Wajah Negara Islam Di Indonesia : Usaha Pembelajaran Sejarah Melalui Materi Konflik Pendahuluan. 10(1), 16-34.

Triwiniastuti, C. S., Kristen, U., Wacana, S., Sabatini, W., Kristen, U., \& Wacana, S. (2019). Implementasi Program Ujian Nasional Di SMA Negeri. (20), 11-12.

Werang Kean, Yohanes Yakobus, D. (2018). Dari Ende Untuk Indonesia: Lawatan Sejarah Daerah Sebagai Sumber Belajar Bagi Generasi Muda. Jurnal Historia, 6(2), 251-262.

Yusutria. (2017). Profesionalisme Guru Dalam Meningkatkan Kualitas Sumberdaya Manusia. Jurnal Curricula, 2(1), 38-46. 